\title{
A Masterpiece of Joan Blaeu
}

\section{Author(s): E. Heawood}

Source: The Geographical Journal, Vol. 55, No. 4 (Apr., 1920), pp. 312-315

Published by: geographicalj

Stable URL: http://www.jstor.org/stable/1781739

Accessed: 26-06-2016 12:18 UTC

\section{Your use of the JSTOR archive indicates your acceptance of the Terms \& Conditions of Use, available at}

http://about.jstor.org/terms

JSTOR is a not-for-profit service that helps scholars, researchers, and students discover, use, and build upon a wide range of content in a trusted digital archive. We use information technology and tools to increase productivity and facilitate new forms of scholarship. For more information about JSTOR, please contact support@jstor.org.

The Royal Geographical Society (with the Institute of British Geographers), Wiley are collaborating with JSTOR to digitize, preserve and extend access to The Geographical Journal 
The British Delegation included a separate geographical section supplied by the Geographical Section of the General Staff and directed by its chief, Colonel Sir Coote Hedley, к.B.E. In the work he had the assistance of two staff officers, Major O. E. Wynne, O.B.E., R.E., with experience of boundary commissions in Africa and of intelligence work at G.H.Q. and the War Office through most of the war, and Captain A. G. Ogilvie, o.B.E., as general geographer. Captain Ogilvie was succeeded in August by Captain Parker, R.E., who remained until the conference dissolved. The section was able to furnish the Delegation and the Congress in general with an ample supply of maps, in which it had the help of a cartographic section R.E. with printing equipment commanded by Major W. Stanford, O.B.E.

The French Delegation relied for its geographical information on three separate organizations, (I) the permanent Geographical Section of the Foreign Office, directed by M. Desbuisson, (2) the Service Géographique de l'Armée represented by General Bourgeois and Lieut.-Col. Bellot, (3) a special geographical section directed by Professor Emm. de Martonne of the University of Paris. M. de Martonne's section dealt with special questions and not with detailed boundary work. It arose from the remains of the Comité d'Étude of war time, which had been officered mainly by Prof. Gallois and the Geography Department of the Sorbonne. In addition to these the French Delegation was happy in finding in M. Pépin a man who combined wide geographical knowledge with a legal training, and so was especially valuable as a connecting link between the geographical and draughting committees.

The senior members of the American Delegation were a few diplomatists and a larger number of students of European affairs-mainly university professors of whom the following are geographers : Prof. Isaiah Bowman, who as director of the American Geographical Society had taken a large share in the work of the Committee of Inquiry, Professors D. W. Johnson, Mark Jefferson, and for part of the time Lawrence Martin, who had been conducting inquiries in Austria-Hungary since the Armistice.

The Italian Delegation had the services of Captain Romagnoli, and Japan was represented on the Geographical Committee by Colonel Nagai.

\section{A MASTERPIECE OF JOAN BLAEU}

$\mathrm{T}$ HROUGH the generous gift of Lieut.-General Sir Arthur Paget, the Society has become possessed of yet another of the masterpieces of seventeenth-century cartography, in the form of a well-preserved specimen of the great World-map in hemispheres issued by the Dutch firm of Blaeu about the middle of that century. This map cannot claim, like the Hondius map of 1608 , to have been previously lost to sight, for a copy exists in the British Museum, but it is still one of the cartographical rarities of its period, and in size it surpasses all its contemporaries, measuring nearly to by 6 feet over all, while 
the diameter of the circles representing the hemispheres is 4 feet 10 inches. By the date of its production cartography had lost perhaps something of the artistic character which it displayed at the hands of the master-engravers of the turn of the century, and the pictorial embellishment so conspicuous in the Hondius maps and the Blaeu map of 1605 has to a large extent disappeared. But the map is still a magnificent production, representing in many respects the high-water mark of map-making in the early modern period.

At the time of this issue-certainly after 1644 , as this date appears in a legend-the original head of the firm, Willem Jansz Blaeu, was already dead (he died in 1638 ), and the dedication is signed by his eldest son, Joan Blaeu, who with his brother Cornelis continued and extended the activities of the firm. No adequate study of the work of the Blaeus as a whole has yet been made, writers like Baudet having given their chief attention to the firm's fortunes under its founder. For this reason no description of the present big map (not mentioned by Baudet) is easily accessible, if such exists at all, and we have no certain information as to the number of copies in existence ; in any case they must be few. That at the British Museum is bound in the huge volume known as the "King's book"-a collection of large Dutch maps presented by Dutch merchants to King Charles II. at the Restoration in I66o.* (This gives a posterior limit for the date.) In order to allow of its insertion therein the map has been divided into its separate hemispheres, which have also been cut round the margins, so that all the subsidiary diagrams and ornamentation which fill up the whole rectangle have been lost. The copy now presented to the Society is perfect, the whole twenty-one sheets (in three horizontal rows of seven each) having been mounted on canvas and framed. This seems to have been done a considerable time after the original date of the map, as the creases left by old folds are still to be seen. The canvas (or linen) is of a finer texture than that on which the earlier large maps of Hondius and Blaeu are mounted.

We have seen that the date must lie between I644 and I66o, and a close study of the details of the map might further reduce the limits of uncertainty. The signing of the dedication by Joan Blaeu only suggests at once that it was written after the death of his brother Cornelis, put down conjecturally as having occurred in $1646 . \dagger$ The individual there complimented is Don Caspar de Bracamonte y Guzman, Count of Peñaranda, who among other titles is described as Plenipotentiary for the signing of the Peace of Westphalia or Münster ("ad universalia Pacis fœdera Monast. Westphal. sancienda Primarius plena

* This volume is mentioned by Evelyn in his 'Diary,' under date I November I660, in describing a visit to " his Majesties cabinet and closset of rarities": "Here I saw a vast book of mapps in a volume neere 4 yards large" (!). In modern times it is referred to by Mr. C. H. Coote in his Introduction to Part 3 of Muller's 'Remarkable Maps' (Amsterdam, 1895). The World-map and others in the same volume are here spoken of as of importance-along with a globe of almost the same date and also by Blaeu -for their early representation of the results of Tasman's voyages. This subject is also discussed by Heeres in his big Tasman volume (Amsterdam, r898), but his silence on the subject of Blaeu's map shows that no copy was accessible to him in Holland. A comparison of the latter with the two hemispheres formerly shown in inlaid work on the floor of the Town-hall at Amsterdam (completed in 1655) would be of interest, and should be possible with the help of a volume of engravings of the Town-hall published at Amsterdam in $\mathbf{r} 66 \mathrm{r}$.

The dedication, with the arms of the high personage to whom it is addressed, appears between the two hemispheres just below the point of junction, and is therefore missing from the B.M. copy. 
cum potestate Legatus ") which ended the Thirty Years' War in 1648. Although Bracamonte y Guzman represented Spain in the negotiations, Spain in the end remained outside the treaty, so it would almost seem that the dedication was written before the actual signing in 1648 , but during the course of the negotiations. They had begun as early as 1643, and Münster had been settled on as the place of meeting two years earlier still. On the other hand, certain indications in the map itself seem to argue, though not conclusively, for a later date. Thus in place of the more or less rough delineation of China to be found in contemporary maps-Hondius and Janssonius, etc.-we find the greatly improved version of the Atlas Sinensis of Martini, published by Blaeu himself as a section of his great atlas in 1655. A point worthy of notice is the totally different style of the engraving of the Chinese portion of the World-map-to be seen especially in the much finer lines by which the rivers are shown-from that of the rest of the map, the incongruity being distinctly marked at the junction of the sheets. This suggests that the sheet containing China may have been re-engraved for a second edition after Martini's material became available, the rest being re-issued in the form in which it originally appeared before $1648 . *$

No valid conclusions as to date can be reached from a comparison with other maps of the time, so inextricable is the confusion occasioned by the mutual piracy carried on by rival firms, and the inconsistencies between different maps in one and the same atlas. Whilst in some parts the World-map embodies new and original information, especially for the Australian region where the results of Tasman's voyages of $1642-44$ are fully utilized (it is here that the date $\mathrm{I} 644$ is given as that of the discovery), in others there is a very close resemblance to earlier maps of Janssonius, which may however themselves have been copied from earlier works of Blaeu. The representation of the St. Lawrence system deserves a word of notice. Although Champlain had shown several of the great lakes so early as $\mathrm{I}_{32}$, and Sanson had drawn them all, apart from the upper parts of Superior and Michigan, in 1652, the Dutch map-makers long ignored this knowledge, and even in Blaeu's Atlas of 1664 hardly a hint of the lake system is given, the map being a close copy of one by Hondius dated 1630$). \dagger$ In the big World-map one large lake is shown beyond Ontario, with uncertain limits to the west, towards which it is said to extend for 300 miles. This representation and statement appear in other maps of about 1660, including one by Nicholas Visscher, and it might be supposed that this had been copied from our World-map ; yet, strangely enough, Visscher's map is itself inserted, duly ascribed to its author, in Blaeu's Atlas of 1662. In South America, a faulty representation of the Amazon system, with its main stream issuing from the "Lake of the Xarayes" at the head of the Paraguay, is also to be found in Janssonius. The lake occurs in all maps of the period, but Blaeu and Janssonius shift it far to the west of its usual position. In the big map Tasman's discoveries are shown, in the main, in agreement with that navigator's own chart,

* Since the above was written a re-examination of the B.M. copy has strengthened the probability of this suggestion. The Chinese sheet there conforms to the style of the others, and gives the older representation of the geography. Its subsequent re-engraving supports the view that the map was originally made in the forties of the 17 th centuryin any case before 1655, otherwise Martini's material would have been incorporated from the beginning. A similar conclusion is suggested by a comparison with the revised map given by Moxon in the third edition of Wright's "Certaine Errors." Dated 1655, it seems to display a knowledge of Blaeu's map.

$\dagger$ The influence of this Hondius map is also traceable, elsewhere, in the big map. 
but though the supposed junction between New Guinea and Australia is prominently indicated, Tasmania is kept quite distinct, nor is there the suggestion, made by Tasman, of a great eastward extension of Australia to the south-east of New Guinea. A singular omission is that of the whole group of the Solomon Islands, already shown by Ortelius and others as early as I587. As compared with earlier maps a characteristic feature is the general elimination of conjectural geography. The west coast of North America ceases just north of the peninsula of Lower California (here shown as an island as in most maps of the period, though its true character had been indicated in maps of a century earlier), and there is a wide ocean between America and Asia in place of the hitherto current "Straits of Anian" ; nor does the conjectural "Terra de Iesso," occupying a large part of the Northern Pacific, find a place in that form. Tasman's work has now banished the great Southern Continent, except in so far as it is represented by Australia.

The projection used for the World-map is the equatorial stereographic, commonly employed for the hemisphere-maps of the period. The prime meridian runs through the island of Tenerife (which we know to have been the startingpoint of the longitude reckoning used in Tasman's great voyage), whilst Janssonius drew the line through Gran Canaria.* The longitude is reckoned throughout eastward from $0^{\circ}$ to $360^{\circ}$, the division between the hemispheres falling at $30^{\circ}$. In the far East the eastward exaggeration of longitude to be seen in some contemporary maps (Sanson and Janssonius, but not Hondius) is avoided, but the common error of the undue extension of Africa and South America in longitude, not finally corrected till the time of Delisle, is still conspicuous.

The whole rectangle is enclosed within a simple but effective border, and the spaces around the main circles are occupied by two hemispherical starmaps (in the top corners); by the northern and southern circumpolar regions (in the bottom corners) - the latter almost entirely water, owing to the clearing away of the Southern Continent; by an oval map of the World as known to the Ancients, closely reproducing the similar map of Ortelius ; and by cosmographical diagrams representing the systems of Ptolemy, Copernicus, and Tycho Brahe, with the last of whom the elder Blaeu had begun his career as assistant. The embellishment of the main map is restricted to pictures of ships, either single or in fleets. Instructions for the measuring of distances on maps on the stereographic projection are given on blank spaces in the oceans.

We have no means of knowing how long this great map continued to be issued, but in any case copies can hardly have been obtainable after 1672, in which year a disastrous fire destroyed almost the whole of Bleau's establishment, with the map-plates and stock, the loss being estimated at no less than 355,000 florins. But its influence can still be traced at a later date, for the map in hemispheres given by F. de Wit in his Atlas. of 1690 , with his own name as author, is virtually a reduction of our big map, with which it closely agrees in all main particulars. De Wit's Atlas contains at least a few maps printed from plates saved from Blaeu's fire. Finally, Verbiest's great Chinese map of 1672 (?) also shows some close resemblances with Blaeu's masterpiece, and agrees precisely in size.

E. HEAWOOD.

* For mention of the various first meridians in use somewhat earlier see Fournal, vol. 53, p. 52. The elder Blaeu had started his longitude from St. Michael in the Azores, as did Hondius and others. 